\title{
Analyzing Writing Tasks in Japanese High School English Textbooks: English I, II, and Writing
}

\author{
Mayumi Kobayakawa (小早川真由美) \\ Graduate School, University of Tsukuba
}

A quantitative comparative analysis of writing tasks in English I, II, and Writing textbooks was conducted in this study. Writing tasks in the textbooks were classified into four categories: controlled writing, guided writing, translation, and free writing; and 14 subcategories. The results of the analysis show that both English I and II textbooks featured mostly controlled writing tasks and fill-in-the-blank with translation tasks, while Writing textbooks included various translation and controlled writing tasks. Overall, guided writing and free writing tasks rarely appeared in the textbooks analyzed. According to the Japanese government's (MEXT) course of study, writing instruction is generally related to free writing tasks. Therefore, free writing skills are necessary to develop students' practical communication abilities as defined by MEXT. These findings suggest that teachers need to support the development of practical communication abilities by proactively increasing the free writing activities in English classes.

高等学校英語教科書における「書くこと」の課題比較分析:英語 I・II、ライティング について

本研究では、英語 I・II、ライティング教科書における「書くこと」の課題の量的比較分析を行 つた。分類方法としては、教科書の書く活動を制限作文、誘導作文、和文英訳、自由英作文の4 つに大別し、さらにこれらの活動を14種類の課題に分類した。分析結果によると、英語 I ・II 教 科書では制限作文や日本文を見て一文埋める問題、ライティング教科書では和文英訳や制限 作文の課題が多く設定されていた。全体的な特徵として、誘導作文と自由英作文の課題の占め

JALT Journal, Vol. 33, No. 1, May 2011 
る割合は少なかった。「書くこと」に関する学習指導要領の記述内容は主に自由英作文の課題と 関連していることから、文部科学省が定義する「実践的コミュニケーション能力」を育成するため には、自由英作文を書く技能が必要である。したがって、英語授業における書く活動では、自由 英作文を書く機会を積極的に増やすことにより、「実践的コミュニケーション能力」の育成を支援 する必要があると示唆される。

I $n$ recent years, the course of study for upper secondary schools mandated by the Ministry of Education, Culture, Sports, Science and Technology, Japan (MEXT, the former Ministry of Education, 1999) has emphasized the importance of students actively communicating in English. The primary focus has been on listening and speaking activities combined with the introduction of oral communication courses (OC I and II) into the English curriculum. A study by Ueda (1999) found that writing activities have been generally disregarded. Writing, however, is also an important aspect of communication. This is especially evident, for instance, in the growing use of email as a means of communicating information and ideas.

The secondary level course of study (MEXT, 1999) states that its overall objectives are to develop students' practical communication abilities in such areas as understanding information, noting the speaker's or writer's intentions, and expressing personal ideas. In writing, practical communication means expressing information and ideas through written text (Niisato, 2000). In the MEXT course of study, writing instruction is generally related to free writing tasks; therefore, free writing skills are necessary to develop students' practical communication abilities as defined by MEXT. In order to achieve this objective, the authorized textbooks need to provide appropriate tasks for students. Currently, these textbooks feature various activities, exercises, and drills to help students acquire basic writing skills based on grammar and vocabulary knowledge in English, but it is also important to set various tasks that foster students' practical communication skills in writing to achieve the goals outlined by MEXT (1999).

In the present study, a representative sample of authorized English textbooks for the courses English I, II, and Writing have been analyzed to evaluate whether the descriptive contents of the course of study (MEXT, 1999) are reflected in the textbooks. In terms of goals, English I expects teachers to instruct learners through comprehensive communication activities including listening, speaking, reading, and writing using everyday topics, assuming that students have learned an adequate amount of English in junior high school. In English II, based on what has been learned in English I, teachers instruct learners to perform comprehensive communication activities 
through the use of a wider variety of topics. In the course Writing, which is based on required English classes such as Aural/Oral Communication I (OCI) or English I, teachers instruct learners how to communicate accurately by writing down information and ideas in English.

It would seem that to accomplish the MEXT practical communication goals, textbooks used in English classes should contain writing tasks aimed at improving practical communication abilities. Besides evaluating the writing tasks in various textbooks, this study seeks to develop a classification of writing tasks that are necessary for the development of competence in practical written English communication. Based on the results of this comparative analysis, the researcher discusses how textbooks might be adapted to focus on the more communicative elements of writing.

\section{Literature Review}

\section{Previous Studies of Language Teaching Materials}

To date, research on English textbooks or materials used in the Japan context is limited to only a few studies. In countries outside Japan, several comprehensive studies (see Cunningsworth, 1995; Grant, 1987; Littlejohn, 1992; McGrath, 2002; Tomlinson, 1998, 2002) have been conducted on materials being used for language teaching. They proposed several practical models for material evaluation which enable materials to be analyzed in greater detail. In contrast, in Japan, surprisingly few analyses of English textbooks have been carried out. In a somewhat dated study, Wada (1997) pointed out that since the authorization of school textbooks became a political issue in postwar Japan, research regarding textbooks has been ignored as an object of demonstrative study. In addition, according to Fukazawa (2009), while everyone acknowledges the importance of textbooks and teaching materials in activities related to English education, there has been little useful discussion about these materials. In the field of English writing, some researchers have analyzed English textbooks approved for use by MEXT (e.g., Kurihara, Hourai, Hirao, Ko, \& Ka, 1996; Tezuka, 1997), though only a few empirical studies on teaching materials for writing have been conducted (Komuro, 2001).

\section{Teaching Writing in ESL/EFL Classes}

As represented in Raimes's taxonomy (1983, pp. 5-6), the components of writing are likened to the spokes of a wheel, each representing the tasks 
that writers face as they produce a piece of writing. Raimes defined writing as the "clear, fluent, and effective communication of ideas" and presented the following nine components of writing: "syntax (e.g., sentence structure, sentence boundaries, and stylistic choices), grammar (e.g., rules for verbs, agreement, articles, and pronouns), mechanics (e.g., spelling and punctuation), word choice (e.g., vocabulary and idiom), organization, content, the writer's process (e.g., getting ideas, getting started, writing drafts, and revising), audience, and purpose" (p. 6).

As the Japanese course of study has developed over the years, the writing course content has aimed to cover wide areas such as language forms, emphasis on the purpose and the process of writing, and being aware of the reader. However, criticisms have been raised which suggest that writing instruction in Japan has for too long fallen short of covering what is needed to effectively teach writing. As early as the mid-1990s, Midorikawa (1994), for example, pointed out that in terms of traditional approaches to teaching writing, the teaching of some components (i.e., content, the writer's process, audience, and purpose) presented by Raimes (1983) was still insufficient, and suggested that it is essential for instruction to include focus on these components of writing when teaching writing as a means of practical communication. Considering the criticisms of the pre-2001 MEXT approved textbooks, it is important to determine whether recent textbooks are adequately presenting appropriate tasks for teaching the necessary components of writing instruction to accomplish the MEXT goals.

\section{Writing Tasks for Japanese EFL Learners}

Only a few studies have attempted to systematically classify and analyze English writing tasks in Japanese textbooks, including activities, exercises, and drills. Older studies such as Kitauchi (1985) investigated the techniques of controlled writing and classified them into five categories: (a) copying (e.g., dictation, dicto-comp), (b) substitution table/frame, (c) rewriting (e.g., conversion, substitution, sentence combining), (d) completion (e.g., fill-inthe-blank, question-answer, sentence reordering), and (e) addition. Some years later, Noda (1991) designated seven categories of controlled writing tasks: (a) alternation, (b) completion, (c) question-answer, (d) substitution, (e) sentence combining, (f) sentence expansion, and (g) dictation. Yamane (1993) defined five categories of exercises that focused on writing in English II C textbooks: (a) fill-in-the-blank, (b) sentence ordering, (c) translation, (d) oral composition, and (e) free composition. Finally, Tezuka (1997) grouped writing drills into 15 categories, including (a) direct-translation-of-a-whole- 
sentence, (b) filling in blanks of a single sentence with translation, and (c) giving the beginning of a sentence and getting students to write the rest without translation. To the author's knowledge, no studies have persisted within this research trajectory of classifying and analyzing English writing tasks in Japanese textbooks.

A review of these previous studies suggests that writing tasks can be classified into three main groups: (a) controlled writing (including guided writing), (b) translation, and (c) free writing. According to Raimes's (1983) study, for controlled writing and translation students need the following components of writing: syntax, grammar, mechanics, and word choice. In contrast, free writing requires all of Raimes's components of writing: syntax, grammar, mechanics, word choice, organization, content, the writer's process, audience, and purpose. Therefore, it is important for both teachers and students to integrate all components in the production of a text, as presented in Raimes's taxonomy.

\section{Purpose of the Present Study}

The present study particularly focused on writing ability and considered writing tasks focusing on practical communication skills. The purpose of the study was to perform a quantitative comparative analysis of writing tasks in Japanese high school English textbooks (i.e., English I, II, and Writing textbooks) to determine what tasks are included for developing students' practical communication abilities. Consequently, the specific research question (RQ) of the present study was as follows:

RQ: What types of writing tasks are present in the designated textbooks for English I, English II, and Writing?

\section{Method}

\section{Materials}

In Japanese upper secondary schools, the English course is divided into six classes: Aural/Oral Communication I (OCI), Aural/Oral Communication II (OCII), English I, English II, Reading, and Writing. Since this study specifically focuses on writing ability, the researcher has confined the materials for analysis to English I and II and Writing textbooks. It should be noted, however, that English I and II focus on language activities in the four skill areas (listening, speaking, reading, and writing) which should be comprehensively 
integrated in instruction (MEXT, 1999). English II should, in principle, be taught after English I. Writing should, in principle, be taught after either OC I or English I. The English I class meets three class periods a week, while the English II and Writing classes each meet four class periods a week.

Table 1. Materials

\begin{tabular}{lccc}
\hline Publisher & English I & English II & Writing \\
\hline Sanseido & Crown English & Crown English & Crown English \\
& series I & series II & writing \\
Kirihara & Pro-vision English & Pro-vision English & Pro-vision English \\
Shoten & course I & course II & writing \\
& Unicorn English & Unicorn English & Unicorn English \\
Bun-Eido & course I & course II & writing \\
& Vivid English & Vivid English & Vivid writing \\
Daiichi & course I & course II & \\
Gakushusha & Big Diper English & Big Dipper English & Big Dipper writing \\
Suken & course I & course II & course \\
Shuppan & Bit
\end{tabular}

Note. English I textbooks were revised in 2007. English II and Writing textbooks were revised in 2008.

Table 1 shows the list of the high school English textbooks targeted for analysis in the present study, chosen from all the MEXT-approved English textbooks published in Japan. They are a total of 15 books, five series of three textbooks chosen from the top ten in sales (see Watanabe, 2010).

\section{Procedures}

Kobayakawa $(2008,2009)$ drew up criteria for the analysis of writing tasks using studies by Kitauchi (1985), Noda (1991), Rivers (1981), Tezuka (1997), and Yamane (1993). According to Komuro (2001), the definitions of controlled writing and guided writing differ depending on the researcher. The present study distinguished between these two types based on the studies by Byrne (1979) and Finocchiaro and Brumfit (1983), which note that controlled writing tasks focus on language forms such as grammatical structure and vocabulary, while guided writing tasks focus on meaning (or content) rather than language forms. Therefore, in the present study, controlled 
writing refers to tasks in which students practice predetermined language forms, and the aim is formal linguistic accuracy, not self-expression. Guided writing differs in that the language is increasingly based on each student's self-expression, not just a rearrangement of the words given in a textbook.

Based on these definitions, the writing activities of the textbooks were classified into four categories: (1) controlled writing, (2) guided writing, (3) translation, and (4) free writing. These four were sub-categorized further into 14 writing tasks. In order to verify the reliability of the author's analysis of writing tasks in textbooks, first, $30 \%$ of all the writing tasks were classified by the author and separately by another reader with a background in English language teaching. The classification performed by both readers in terms of the possible writing tasks is shown in Table 2. Through follow-up discussion, we arrived at a consensus about whether there were any differences in classification. The remaining $70 \%$ of the writing tasks were then analyzed and categorized by the author.

\section{Table 2. Classification of Writing Tasks (See Appendix for examples)}

Categories of writing Writing tasks

(1) controlled writing (a) dictation

(b) conversion

(c) sentence combining

(d) fill-in-the-blank without translation

(e) question-answer

(f) sentence ordering

(g) addition

(h) summary writing

(2) guided writing (i) fill-in-the-blank without translation

(j) question-answer

(k) addition

(3) translation

(l) direct-translation-of-a-whole-sentence

(m) fill-in-the-blank with translation

(4) free writing

(n) free composition

(5) other

Note. The summary writing task (h) in the textbooks has been classified as controlled writing (1) because the task requires students to fill in blanks with the most appropriate word or select one from multiple options to match the contents of the text. Writing tasks in the category other (5) had no application to the other four 
categories. Most of the tasks in other (5) were featured in the textbooks as prewriting activities.

\section{Data Analysis}

The number of writing tasks in each category in the chosen English textbooks was expressed as a percentage and considered as a raw score. In order to confirm any significant differences among the textbooks within the five categories of writing tasks, chi-square tests and residual analyses were conducted using SPSS software version 17.0E.

\section{Results and Discussion}

\section{Analysis From the Inter-Textbook Perspective}

\section{English I Textbooks}

The number of tasks in each writing exercise in English I textbooks was counted. Figure 1 presents the raw counts of the writing tasks shown as a percentage of the total number of tasks in the five English I textbooks.

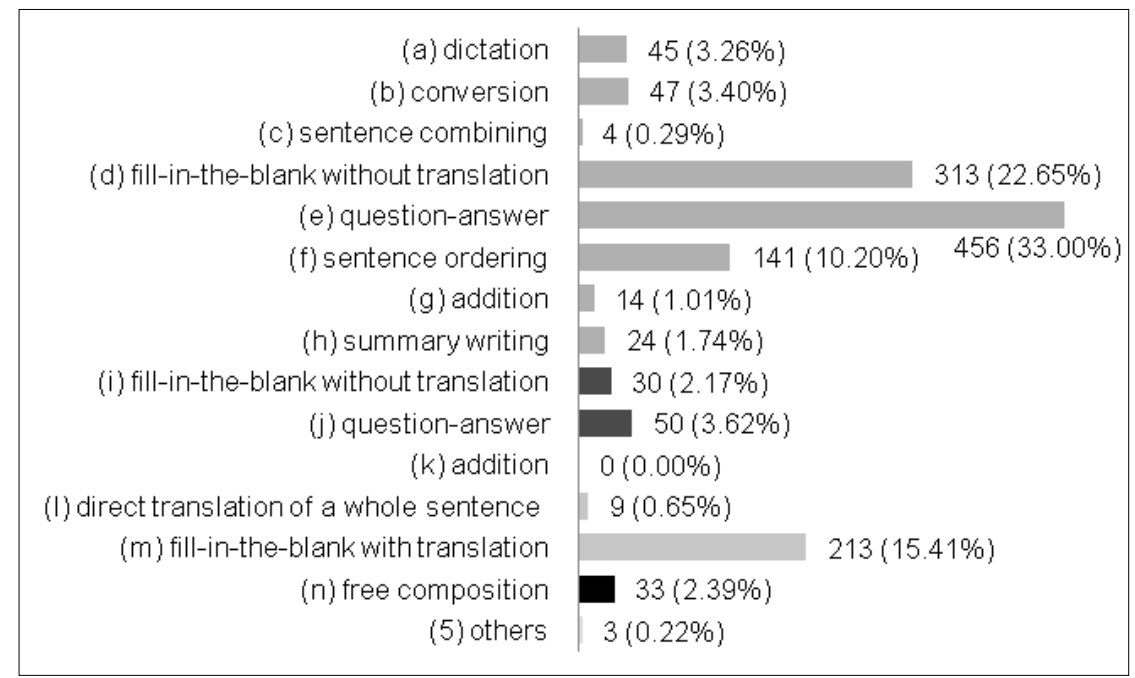

Figure 1. Number and Percentage of Writing Tasks in Five English I Textbooks 
The results showed that the dominant type of exercise in each textbook was controlled writing $(75.54 \%$ in total). Within these controlled writing tasks, (a) dictation, (d) fill-in-the-blank without translation, (e) questionanswer, and (f) sentence ordering appeared in all five English I textbooks. Guided writing accounted for only $5.79 \%$ of the writing tasks. In the English I textbooks analyzed, most writing tasks focused on language forms such as grammatical points, syntactic structure, and vocabulary.

Within the category called translation, (m) fill-in-the-blank with translation appeared the third highest number of times among the 14 writing tasks (15.41\%). All five textbooks included this task. On the other hand, task (l) direct-translation-of-a-whole-sentence was included in only two textbooks (Pro-Vision 1.61\% and Unicorn 1.33\%). One reason for this may be that it is quite difficult for 1st-year high school students who use English I textbooks to translate Japanese sentences into English.

Free composition (n) tasks were included in all five textbooks but constituted less than $4 \%$ of the total number of writing tasks. In addition, free composition tasks were inconsistently included; the highest number of these tasks (12) appeared in the Unicorn series, but only one was found in the Pro-Vision series. However, Pro-Vision included more guided writing tasks, such as (i) fill-in-the-blank without translation, than other textbooks (11.65\% of the total number of writing tasks).

In addition to the foregoing analysis, in order to investigate the main writing tasks in each English I textbook, SPSS software was used for data analysis and a chi-square test was conducted. The results show that significant differences were found in the frequency profiles of the tasks in the five categories of writing in each textbook: $\chi^{2}(16, N=1382)=81.03, p=.00$. Furthermore, a residual analysis was conducted to reveal the main features of all five writing tasks in each textbook, and Table 3 presents the results of the adjusted standardized residual (ASR) that was calculated to verify these differences. Any adjusted standardized residual greater than 2.0 (and lower than -2.0) indicates that the observed number of cases is significantly higher or lower than expected.

As can be seen in Table 3, the number of tasks of (1) controlled writing, (2) guided writing, (3) translation, and (4) free writing among the various textbooks differed significantly at the .05 level. Presented below are the main features of writing tasks in each English I textbook:

1. Crown had a significantly high number of guided writing tasks;

2. Pro-Vision had a significantly high number of guided writing 
tasks but a significantly low number of free writing tasks;

3. Unicorn had a significantly low number of guided writing tasks;

4. Vivid had a significantly high number of translation tasks but a significantly low number of guided writing tasks; and

5. Big Dipper had a significantly high number of controlled writing tasks but a significantly low number of guided writing and translation tasks.

Table 3. Adjusted Standardized Residuals in English I Textbooks

\begin{tabular}{|c|c|c|c|c|c|c|c|c|c|c|}
\hline \multirow{2}{*}{$\begin{array}{l}\text { Writing } \\
\text { activities }\end{array}$} & \multicolumn{2}{|c|}{ Crown } & \multicolumn{2}{|c|}{ Pro-Vision } & \multicolumn{2}{|c|}{ Unicorn } & \multicolumn{2}{|c|}{ Vivid } & \multicolumn{2}{|c|}{ Big Dipper } \\
\hline & $n$ & $A S R$ & $n$ & $A S R$ & $n$ & $A S R$ & $n$ & $A S R$ & $n$ & $A S R$ \\
\hline $\begin{array}{l}\text { (1) control- } \\
\text { led writing }\end{array}$ & 218 & -1.5 & 177 & -1.8 & 294 & 1.3 & 170 & -1.4 & 185 & $3.5^{*}$ \\
\hline $\begin{array}{l}\text { (2) guided } \\
\text { writing }\end{array}$ & 35 & $4.9^{*}$ & 29 & $4.4^{*}$ & 6 & $-4.1^{*}$ & & $-2.3^{*}$ & 4 & $-2.7^{*}$ \\
\hline $\begin{array}{l}\text { (3) transla- } \\
\text { tion }\end{array}$ & 41 & -1.3 & 42 & 0.4 & 63 & 0.4 & 54 & $3.1^{*}$ & 22 & $-2.6^{*}$ \\
\hline $\begin{array}{l}\text { (4) free } \\
\text { writing }\end{array}$ & 8 & 0.3 & 1 & $-2.3^{*}$ & 12 & 1.2 & 5 & -0.3 & 7 & 0.9 \\
\hline (5) other & 0 & -0.9 & 0 & -0.8 & 2 & 1.5 & 1 & 0.7 & 0 & -0.8 \\
\hline
\end{tabular}

Note. ASR $=$ adjusted standardized residuals. Any adjusted standardized residual greater than $|2.0|$ is significant at $p<.05$.

${ }^{*} p<.05$.

\section{English II Textbooks}

Figure 2 presents the percentages of writing tasks in the five designated English II textbooks. These results show that the dominant type of exercise in each textbook was controlled writing (74.71\% in total). In these controlled writing tasks, (c) sentence combining, (d) fill-in-the-blank without translation, (e) question-answer, and (f) sentence ordering were included in all five textbooks. Only $4.85 \%$ of the tasks were guided writing tasks. As was the case with the English I textbooks analyzed, most writing tasks in English II textbooks focused on language forms such as grammatical points, syntactic structure, and vocabulary. Regarding translation tasks, (m) fillin-the-blank with translation appeared the third highest number of times among all 14 writing tasks (12.71\%). In contrast, (l) direct-translation-of-a- 
whole-sentence was included in only two textbooks (Vivid $5.99 \%$ and Unicorn $10.64 \%$ ). Although free writing (free composition) tasks were featured in all five textbooks, they accounted for less than $5 \%$ of the total number of tasks. The number of tasks was also inconsistent in the textbooks analyzed; the highest number of free composition tasks was 17 in the Unicorn series, and the lowest number was 4 in the Vivid series.

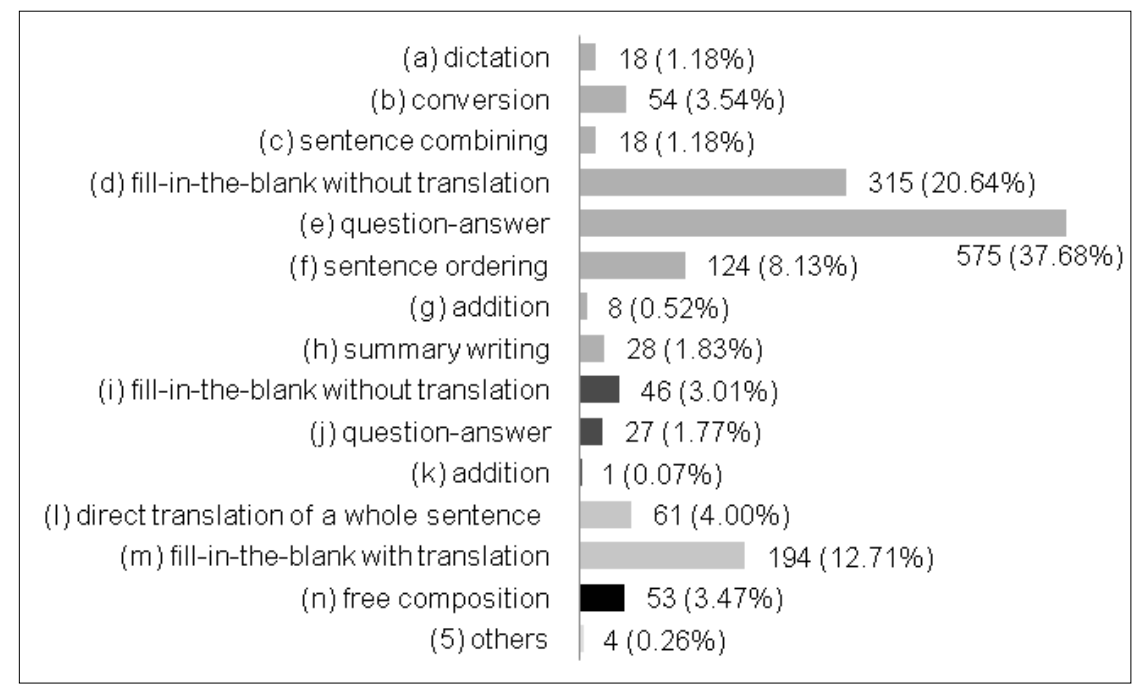

Figure 2. Number and Percentage of Writing Tasks in Five English II Textbooks

In order to investigate the main features of writing tasks in each English II textbook, a chi-square test was conducted. According to the results, significant differences were found among the frequencies in the five writing categories in each textbook: $\chi^{2}(16, N=1526)=64.98, p=.00$. Furthermore, a residual analysis was conducted, and Table 4 presents the results of the adjusted standardized residuals calculated to verify these differences.

As can be seen in Table 4, the following are the main features of the writing tasks in each English II textbook (note that there were no significant differences in the Crown and Vivid series):

1. Pro-Vision had a significantly high number of guided writing tasks and a significantly low number of controlled writing tasks; 
2. Unicorn had a significantly high number of controlled writing tasks and a significantly low number of guided writing and translation tasks; and

3. Big Dipper had a significantly low number of guided writing tasks.

Table 4. Adjusted Standardized Residuals in English II Textbook

\begin{tabular}{lcccccccccc}
\hline Writing & \multicolumn{3}{c}{ Crown } & \multicolumn{2}{c}{ Pro-Vision } & \multicolumn{2}{c}{ Unicorn } & \multicolumn{2}{c}{ Vivid } & \multicolumn{3}{c}{ Big Dipper } \\
\cline { 2 - 10 } activities & $n$ & $A S R$ & $n$ & $A S R$ & $n$ & $A S R$ & $n$ & $A S R$ & $n$ & $A S R$ \\
\hline $\begin{array}{l}\text { (1) control- } \\
\text { led writing }\end{array}$ & 260 & -1.2 & 168 & $-3.6^{*} 342$ & $3.4^{*} 199$ & -0.1 & 171 & 1.0 \\
$\begin{array}{l}\text { (2) guided } \\
\text { writing }\end{array}$ & 23 & 1.6 & 30 & $5.6^{*}$ & 5 & $-4.1^{*}$ & 13 & 0.0 & 3 & $-2.6^{*}$ \\
$\begin{array}{l}\text { (3) transla- } \\
\text { tion }\end{array}$ & 61 & 0.1 & 49 & 1.2 & 57 & $-2.1^{*}$ & 51 & 1.2 & 37 & 0.0 \\
$\begin{array}{l}\text { (4) free } \\
\text { writing }\end{array}$ & 16 & 1.2 & 8 & -0.3 & 17 & 0.7 & 4 & -1.9 & 8 & 0.1 \\
(5) others & 0 & -1.1 & 0 & -0.9 & 2 & 1.0 & 0 & -0.9 & 2 & $2.0^{*}$ \\
\hline
\end{tabular}

Note. ASR = adjusted standardized residuals.

${ }^{*} p<.05$.

\section{Writing Textbooks}

The percentages of writing tasks included in the five Writing textbooks are presented in Figure 3. In terms of controlled writing tasks (39.40\% in total), (d) fill-in-the-blank without translation (18.49\%) appeared most frequently, followed by (f) sentence ordering (12.01\%), and (a) dictation (4.51\%). These three tasks were included in all of the textbooks analyzed. Furthermore, (i) fill-in-the-blank without translation, which is one of the guided writing tasks, also appeared in all five textbooks (2.89\% in total). Thus, the results showed that Writing textbooks had a lower number of controlled and guided writing tasks in comparison with English I and II textbooks.

With respect to the translation tasks $(\mathrm{m})$ fill-in-the-blank with translation and (1) direct-translation-of-a-whole-sentence, percentages for these in the Writing textbooks (51.71\% in total) were considerably higher than in English I (16.06\% in total) and English II (16.71\% in total) textbooks. In particular, for (l) direct-translation-of-a-whole-sentence tasks, both English I (0.65\%) and English II (4.00\%) included a very low percentage, while all 
the Writing textbooks included these tasks at a high percentage (24.06\%). In this respect, the Writing textbooks were different from English I and II textbooks. On the English composition portion of university entrance examinations, students are asked to perform a number of Japanese-English translation tasks (Nakano, 2009). The focus of the exams appears to have an influence on the types of writing tasks presented in Writing textbooks.

All of the textbooks analyzed included free writing. The number of free writing tasks in the Writing textbooks was higher than in English I and II textbooks. However, the percentage in all five textbooks was no more than $5 \%$. The free writing task types included: (a) to organize and write down one's own ideas, and (b) to write with due attention to the structure and development of passages. The Writing textbooks included paragraph or essay writing activities of self-expression (e.g., descriptive and summary writing) of about 50 to 100 words. Nonpersonal topics (e.g., environment, social problems, international exchanges, and volunteer activities) were presented as topics of free composition.

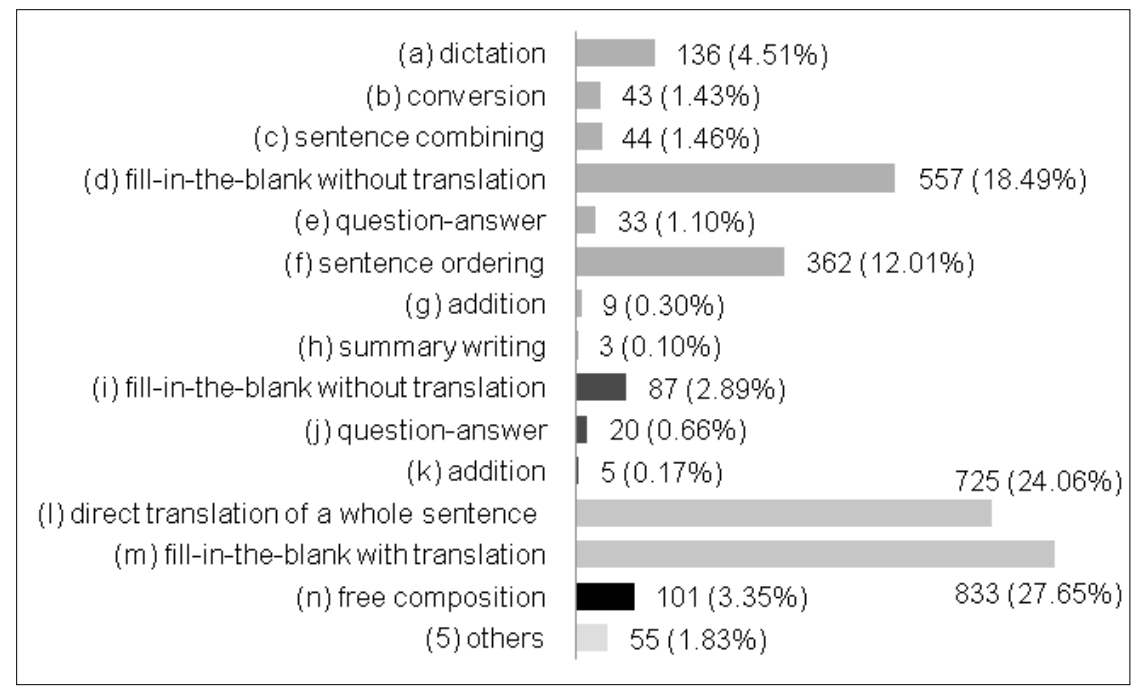

Figure 3. Number and Percentage of Writing Tasks in Five Writing Textbooks

In addition to the preceding analysis, the main features of all five writing tasks in each Writing textbook were investigated using a chi-square test. The results of an analysis of frequency data of writing tasks showed statistically 
significant differences among the five writing categories in each of the textbooks: $\chi^{2}(16, N=3013)=191.75, p=.00$. Furthermore, a residual analysis was conducted, and Table 5 presents the results of the adjusted standardized residuals calculated to verify these differences.

Table 5. Adjusted Standardized Residuals in Writing Textbooks

\begin{tabular}{lccccccccccc}
\hline Writing & \multicolumn{3}{c}{ Crown } & \multicolumn{2}{c}{ Pro-Vision } & \multicolumn{2}{c}{ Unicorn } & \multicolumn{2}{c}{ Vivid } & \multicolumn{2}{c}{ Big Dipper } \\
\cline { 2 - 10 } activities & $n$ & $A S R$ & $n$ & ASR & $n$ & ASR & $n$ & ASR & $n$ & ASR \\
\hline $\begin{array}{l}\text { (1) control- } \\
\text { led writing }\end{array}$ & 253 & -0.9 & 340 & $8.0^{*}$ & 164 & $-5.6^{*}$ & 233 & $4.5^{*}$ & 197 & $-5.6^{*}$ \\
$\begin{array}{l}\text { (2) guided } \\
\text { writing }\end{array}$ & 15 & $-2.3^{*}$ & 6 & $-4.2^{*}$ & 30 & $2.2^{*}$ & 37 & $5.0^{*}$ & 24 & -0.1 \\
$\begin{array}{l}\text { (3) transla- } \\
\text { tion }\end{array}$ & 381 & $3.1^{*}$ & 255 & $-6.8^{*}$ & 349 & $5.3^{*}$ & 186 & $-6.2^{*}$ & 387 & $4.1^{*}$ \\
$\begin{array}{l}\text { (4) free } \\
\text { writing }\end{array}$ & 13 & $-2.3^{*}$ & 31 & $2.4^{*}$ & 11 & $-2.1^{*}$ & 17 & 0.3 & 29 & 1.7 \\
(5) others & 7 & -1.7 & 8 & -1.2 & 12 & -0.6 & 7 & -0.7 & 21 & $3.0^{*}$ \\
\hline
\end{tabular}

Note. ASR $=$ adjusted standardized residuals.

${ }^{*} p<.05$.

As shown in Table 5, the numbers of the five writing tasks among the various textbooks differed significantly at the .05 level. The main features of writing tasks in each Writing textbook were:

1. Crown had a significantly high number of translation tasks but a significantly low number of guided writing and free writing tasks;

2. Pro-Vision had a significantly high number of controlled writing and free writing tasks but a significantly low number of guided writing and translation tasks;

3. Unicorn had a significantly high number of guided writing and translation tasks but a significantly low number of controlled writing and free writing tasks;

4. Vivid had a significantly high number of controlled writing and guided writing tasks but a significantly low number of translation tasks; and

5. Big Dipper had a significantly high number of translation tasks but a significantly low number of controlled writing tasks. 
The basic characteristics of writing tasks in the five textbooks revealed by the analysis are summarized as follows: Pro-Vision (53.13\%) and Vivid (48.54\%) emphasized controlled writing tasks while Unicorn (61.66\%), Big Dipper (58.81\%), and Crown (56.95\%) emphasized translation tasks.

\section{Discussion}

The main results of the present study confirm that English I and II textbooks feature many controlled writing tasks; on the other hand, Writing textbooks feature many translation and controlled writing tasks. All of the analyzed textbooks contain a relatively lower number of guided writing tasks.

According to Nuibe (1985), the following sequence of teaching writing has heretofore been applied: (a) translation $\rightarrow$ free writing, and (b) controlled writing $\rightarrow$ guided writing $\rightarrow$ free writing. This sequence is expected to help students achieve accuracy in language forms (e.g., grammatical structure and vocabulary). Judging from the results of the analyses, since a large number of controlled writing and translation tasks are featured in the textbooks, and assuming that teachers follow these textbooks, we would expect these tasks to play a significant role in the writing activities of each English class-although this inference still requires empirical verification. It is necessary to consider how we should utilize these tasks as a basis for free writing in order to develop the students' practical communication abilities.

The various advantages of controlled writing have been cited by researchers such as Kitauchi (1985), Okumura (1991), Owens (1970), and Paulston (1972). For example, it is possible for students to enhance and establish their ability to understand correct grammatical structure by exploiting the potential of controlled writing. Komuro (2001) has also made the case that translation tasks are useful in order to develop ability in writing for practical communication. Based on this rationale, it is also necessary to give students more experience in writing and practicing translation tasks so that they can express their thoughts in English. However, it is dangerous to rely on any single group of writing activities, because each of the three kinds of writing activities has its own function and plays an important role in developing students' writing abilities. Not only grammatical learning for understanding language functions and usage but also activities such as guided writing incorporated into free composition will encourage students to write their own thoughts in English which in turn fosters practical communication abilities. For example, as early as 1967, Dykstra and Paulston compared guided writ- 
ing with free writing and found that participants in their guided writing group built confidence in their abilities to write, and this motivated them to further improve their writing ability.

The analysis has shown that the number of free writing tasks is much lower in some textbooks, although free writing was included to some degree in all of the textbooks analyzed. It is necessary to introduce significantly more free writing tasks, and guided writing tasks as well, in certain textbooks since such tasks are required to develop writing as a practical communication ability.

\section{Conclusion}

The purpose of this study was to perform a comparative analysis of the number of writing tasks in textbooks in three courses, English I, II, and Writing. The main findings of the inter-textbook comparisons corresponding to the research question are as follows:

1. The English I and II textbooks are heavily weighted toward controlled writing tasks (e.g., question-answer, fill-in-the-blank without translation, and sentence ordering) and fill-in-the-blank with translation tasks;

2. Among the five writing textbooks examined, three emphasized translation, while the other two emphasized controlled writing; and

3. The results indicate that, overall, guided writing and free writing tasks are under-represented in all of the textbooks analyzed.

In order to support students in developing practical communication abilities in writing as outlined by MEXT, more effort is needed to configure English writing instruction in such a way that it better achieves the goals of the course of study. In the course of study, the descriptive guidelines for teaching writing are mostly related to free writing tasks in all writing activities. Therefore, writing instruction in English classes should aim to develop students' practical communication abilities by proactively increasing the opportunities for free writing. However, because the analyzed textbooks included so few guided writing tasks and so many controlled writing and translation tasks, it is doubtful that such an unbalanced combination can serve as a bridge to greater ability in free writing. Clearly, there exists a gap in the textbooks between controlled writing and translation on the one hand, and free writing on the other. 
We should note though that the present study analyzed writing tasks with regard to the form of the writing tasks rather than the content. Further investigation is also needed on the sequence of writing tasks. The results do suggest, however, that we need to more carefully consider how to help students advance from simple learning of grammar and vocabulary to entirely independent writing. Based on the analysis of textbooks in this study, it would appear that more guided writing tasks are required in textbooks in order to successfully bridge the gap between controlled writing and translation, and free writing.

\section{Acknowledgment}

I wish to express my deepest gratitude to Akira Kubota for his encouragement and guidance throughout the project.

Mayumi Kobayakawa is a PhD student at the University of Tsukuba. She has taught for 3 years at a private high school in Aichi Prefecture.

\section{References}

Byrne, D. (1979). Teaching writing skills. London: Longman.

Cunningsworth, A. (1995). Choosing your coursebook. Oxford: Heinemann.

Dykstra, G., \& Paulston, C. (1967). Guided composition. English Language Teaching, 21, 136-141.

Finocchiaro, M., \& Brumfit, C. (1983). The functional-notional approach: From theory to practice. New York: Oxford University Press.

Fukazawa, S. (2009). Kyozai wo miru shiten [The viewpoints of teaching materials]. In S. Miura \& S. Fukazawa (Eds.), Atarashii manabi wo hiraku eigoka jugyo no riron to jissen [Principles and practices of teaching English for opening a new learning] (pp. 80-91). Kyoto: Minerva shobo.

Grant, N. (1987). Making the most of your textbook. London: Longman.

Kitauchi, K. (1985). Seigen sakubun [Controlled writing]. In K. Okihara (Ed.), English no Writing [English writing] (pp. 130-170). Tokyo: Taishukan.

Kobayakawa, M. (2008). English writing activities for practical communication abilities: Comparative analyses of writing tasks in English I textbooks. JABAET Journal, 12, 5-20. 
Kobayakawa, M. (2009). A comparative study of writing tasks in Japanese high school English textbooks. Unpublished master's thesis, University of Tsukuba, Ibaraki, Japan.

Komuro, T. (Ed.). (2001). English Writing ron [Theory of English writing]. Tokyo: Kagensha.

Kurihara, M., Hourai, T., Hirao, M., Ko, M., \& Ka, H. (1996). Koukou eigo kyoukasho no bunsekiteki kenkyuu [An analysis of high school English textbooks]. The Annual Report of Japanese Association for the Instructional Materials, 7, 70-72.

Littlejohn, A. (1992). Why are English language teaching materials the way they are? Doctoral thesis, Lancaster University, Bailrigg, Lancaster, UK.

McGrath, I. (2002). Materials evaluation and design for language teaching. Edinburgh: Edinburgh University Press.

Midorikawa, H. (1994). Writing. In JACET SLA (Ed.), Daini gengo shuutoku kennkyuu ni motoduku saishin no eigo kyouiku [Up-to-date English education based on second language acquisition research] (pp. 287-299). Tokyo: Taishukan.

Ministry of Education. (1999). Koutougakkou gakushuu shidou youryou kaisetu: Gaikokugo hen, English hen [The course of study for upper secondary school: Foreign languages]. Tokyo: Kairyudo.

Nakano, T. (2009). Bunryo hen [Quantity]. In K. Kanatani (Ed.), Kyokasho dakede daigaku nyushi wa toppa dekiru [If we use textbooks, we can pass university entrance examinations] (pp. 99-168). Tokyo: Taishukan.

Niisato, M. (2000). Writing no bamen wo dou settei suruka [How to set situations for writing]. The English Teacher's Magazine, 11, 11-13.

Noda, T. (1991). Kakukoto no shidou [Writing instruction]. In T. Horiguchi (Ed.), Gendai eigo kyouiku no riron to jissen [Modern English teaching: Principles and practices] (pp. 97-104). Tokyo: Seibunsha.

Nuibe, Y. (1985). Jiyuu eisakubun [Free writing]. In K. Okihara (Ed.), English no Writing [English writing] (pp. 170-198). Tokyo: Taishukan.

Okumura, K. (1991). Writing shidou no mondai ten [The issues of English writing instruction]. In S. Ando (Ed.), Eigo kyouiku gendai keyword jiten [Dictionary of keywords in English language education] (pp. 239-241). Osaka: Zoshindo.

Owens, R. J. (1970). Teaching English composition. RELC Journal, 1, 119-126.

Paulston, C. B. (1972). Teaching writing in the ESOL classroom: Techniques of controlled composition. TESOL Quarterly, 6, 33-59.

Raimes, A. (1983). Techniques in teaching writing. New York: Oxford University Press. 
Rivers, W. M. (1981). Teaching foreign language skills (2nd ed.). Chicago: University of Chicago Press.

Tezuka, T. (1997). A classification of writing drill types. The Chubu English Language Education Society, 27, 95-102.

Tomlinson, B. (Ed.). (1998). Materials development in language teaching. Cambridge: Cambridge University Press.

Tomlinson, B. (Ed.). (2002). Developing materials for language teaching. Cambridge: Cambridge University Press.

Ueda, M. (1999). Seito ga ikiiki to torikumu writing shidou [Writing instruction in which students work lively]. In H. Ito (Ed.). Communication no tameno yon ginou no shidou [Teaching of four skills for communication] (pp. 135-152). Tokyo: Kyoiku shuppan.

Wada, M. (1997). Nihon ni okeru eigo kyouiku no kenkyuu: Gakushu shidou youryou no riron to jissen [The research of English education in Japan: The theory and practice of the course of study]. Tokyo: Kirihara shoten.

Watanabe, A. (2010). 2010 nendo koukou kyoukasho saitaku jyoukyou: Monkashou matome [The selection of the textbooks for Japanese upper secondary schools in 2010: The compilation by MEXT]. Naigai Kyoiku, 5967, 4-11.

Yamane, K. (1993). English writing textbooks ni nozomu [Hopes for English writing textbooks]. The English Teacher's Magazine, 2, 44-45.

\section{Appendix (Examples of Writing Tasks)}

(1) Controlled writing

(a) dictation

英語を聞いて下線部を補い、文を完成させなさい。[Listen to the passage and fill in the blanks.]

Nana looked sad when she She had lost her contact lens and though she was looking for it . Will knew how she felt, so he told her that with glasses.

(b) conversion

分詞構文を用いて、次の文を書きかえなさい。[Rewrite the English sentence with the same meaning by using a participle construction.]

Because they didn't know who he was, they didn't speak to him. 
(c) sentence combining 以下の2文を適当な接続詞を使って結びつけなさい。[Combine the two sentences by using a conjunction.]

She graduated from the University of Hawaii. She was employed as an assistant English teacher in Japan.

(d) fill-in-the-blank without translation

（）に適切な関係代名詞・関係副詞を入れなさい。[Fill in the blank with an appropriate relative pronoun or relative adverb.]

Yesterday, I happened to see a classmate of my junior high school; ( ) was a pleasant surprise.

(e) question-answer

上の学校新聞の記事を読んで、次の質問に英語で答えなさい。[Read the school newspaper article, and then answer the question in English.] When was the school festival held?

(f) sentence ordering

（）内の語句を並べ替えなさい。[Put the words in parentheses in order.] 今日出来ることは明日に延ばすな。Don't (what / you / put off / can / tomorrow / till) do today.

(g) addition

※いろいろな修飾語句や節などを付け加えて文を長くする。 [Expand the sentence with modifiers.]

(例) The prize will be a vase.

The prize will be a beautiful vase.

The prize will be a beautiful old crystal vase.

(h) summary writing

以下のパラグラフは「姓名のローマ字表記」に関するエッセイの要約です。要約 の手順を参考にして、文中の空欄を埋めなさい。次に音声を聞いて確認しな さい。[The following paragraph is a summary of an essay on Japanese names in romaji (the Roman alphabet). Based on the steps of summary writing, fill in the blanks. Then listen to the answer.] Japanese names, when written in romaji, are usually given in the Western name order. 
(1) reversing our names. For one thing, (2)

For another, (3) ; it gives Westerners a big advantage over Japanese people. These are the reasons why I maintain that (4)

(2) Guided writing

(i) fill-in-the-blank without translation

下線部に適当な語句を入れて、自分自身のことについて書いてみよう。[Fill in the blank about yourself.]

Walking on the streets in my town, I see many

(j) question-answer

次の質問に英語で答えなさい。[Answer the question in English.]

Do you eat breakfast every day?

(k) addition

次の各文を読み、文を3つずつ付け加えて書け。[Read the sentence and add three sentences.]

1. (例) [Example] My friends went to a French restaurant.
A. They ate crepes.
B. They drank wine.
C. They got sick during dinner.

2. Hawaii always has a lot of tourists.
A.
B.
C.

(3) Translation

(l) direct-translation-of-a-whole-sentence

次の日本語を英語で表現しなさい。[Translate the Japanese sentence into English.]

私は、シャーロック・ホームズが事務所を置いていた、ロンドンのベーカー街を訪 れたいといつも思っていました。[I've always wanted to visit Baker Street in London, where Sherlock Holmes had his office.] 
(m) fill-in-the-blank with translation

下線部に適切な語句を補い、日本語と同じ内容の文にしなさい。 [Using the Japanese sentence as a guide, complete the sentence.]

インターネットがなければ、私たちの日々の生活は今日ほど便利ではない だろう。

If our daily life would not be as convenient as it is today.

(4) Free writing

(n) free composition

あなたのクラスメートを紹介する英文を書いてみよう。[Write a paragraph introducing your classmate.]

(例) [Example] Ayako is one of my friends. We call her Aya-chan. She is very friendly. She is good at writing poems.

新学年の始まりは4月と9月ではどちらがよいかについての意見を述べなさ い。 [Write a paragraph to discuss which is better, April or September, for schools to start their school year.] 